\title{
RAINWATER HARVESTING IN KOTA SAMARAHAN
}

\author{
Nasser R. Afshar ${ }^{1}$, Efarina. A. Hamit ${ }^{2}$ \\ ${ }^{1}$ Associate Professor, Department of Civil Engineering, Universiti Malaysia Sarawak, Sarawak, Malaysia \\ ${ }^{2}$ Student, Department of Civil Engineering, Universiti Malaysia Sarawak, Sarawak, Malaysia
}

\begin{abstract}
Water is vital to all forms of life on the Earth, from plants through to animals and humankind. Lack of access to fresh drinking water is one of the major and important constraints to health and development in many countries. Rainwater harvesting refers to the collection and storage of rain. It is still popular in places with limited water resources. Recent drought in a rainy climate throughout the world remind how quickly other countries can run short of water. Since Malaysia has high rainfall intensity, it does not means that Malaysian should not worry about scarcity of water supply. Even the annual rainfall is high and sufficient enough to be consumed, most of the rainwater tend to flow away. The environmental issue such as flooding, global warming and pollution are getting serious day by day due to a rapid development processes in Malaysia. To pursue the need for a more sustainable development, it is possible to implement rainwater harvesting which has been recognized as one of the innovative solutions as an alternative water supply for non-, portable purposes. Designing water harvesting systems into new construction allows the homeowner to be more elaborate and thorough in developing a system. In the case of very simple systems, the payback period may be almost immediate. The objective of this study is to estimate the potential of rainfall to be stored for domestic use and design the rainwater harvesting system using gravitational force suitable for the selected house in Kota Samarahan area. It has been shown that the rainwater harvesting system can support the water demand of the selected house throughout a year even during the dry season. The cost of installation and yearly maintenance for proposed rainwater harvesting is lowered by 59.16 percent as compared with similar rainwater system which is installed on the ground level.
\end{abstract}

Keywords: Water, Rainwater harvesting, Water harvesting system, Demand and Storage capacity

\section{INTRODUCTION}

WATER is one of the most important substance in everyday life. About seventy one percent of the earth's surfaces are covered by water, with the remainder consisting of continents and islands which together have many lakes and other sources of water that contribute to the hydrosphere. Next to oxygen, water is essential component for all living organisms in daily life. Ninety- seven percent of all water on the earth surface is saline or seawater. Only three percent of glacier and groundwater contribute water to the world. Sea water can be converted to fresh water, but the process is very expensive. According to International Commission On Large Dams [1], Demand for water is steadily increasing throughout the world. During the past three centuries, the amount of water withdrawn from freshwater resources has increased by a factor of 35 , world population by a factor of 8. With the present world population of 5.6 billion still growing at a rate of about 90 million per year, and with their legitimate expectations of higher standards of living, global water demand is expected to rise by a further 2-3 percent annually in the decades ahead, but freshwater resources are limited and unevenly distributed.

Malaysia receives rainfall from $2000 \mathrm{~mm}$ to $4000 \mathrm{~mm}$ annually where it is greatly influenced by two monsoon periods in November to March and May to September. Malaysia's water consumption is alarmingly high and increasing every year. Water consumption per capita per day increases about 7.6 liters per year. This increase in water consumption is not matched by an increase in water reserves. Malaysia's water reserves per capita per day is declining at a rate of 5.8 liters per year. At this rate, Malaysia would be left with nearly no water reserves by 2025. Therefore, the study of rainfall harvesting plays an important role to a country such as Malaysia where the rain is abundant.

Rain harvesting can be defined as a collection of rainwater from catchment surface in order to increase the water availability whenever water shortage occurs. According to [2]-[3], The primary idea of water harvesting is for domestic and agricultural use. Rainwater harvesting is to ensure that the rainfall is used effectively before it has run away into the river or disappear due to evaporation.

\section{WATER COLLECTION AND DISTRIBUTION} \section{SYSTEM}

A simple system usually consists of a catchment area, and a means of distribution system, which operates by gravity. Water are collected on roofs, paved areas or the soil surface. Gravity moves the water to where it can be used. In some cases, small containers are used to hold water for later use. A catchment area is any area from which water can be harvested. The best catchments have hard, smooth surfaces, such as concrete or metal roofing material. The amount of water harvested depends on the size, surface texture, and slope of the catchment area. 
The distribution system connects the catchment area to the landscape holding area. Rainwater is collected on the roof and transported with gutters to a storage tank, where it provides water at the point of consumption. Distribution systems direct water flow, and can be very simple or very sophisticated. For example, gutters and downspouts direct roof water to a storage tank, holding area, and gently sloped sidewalks distribute water to a planted area. Hillsides provide a perfect situation for moving water from a catchment area to a holding area.

\section{METHODOLOGY}

The most common technique in urban areas is rooftop rainwater harvesting [4]. Rainwater is collected on the roof and transported with gutters to a storage tank (which is installed above the ground in this study) where it provides water at the point of consumption. The basic rule for sizing any rainwater harvesting system is that the volume of water that can be captured and stored must equal or exceed the volume of water used. The variables of rainfall and water demand determine the relationship between required catchment area and storage capacity. In some cases, it may be necessary to increase catchment surface area by addition to capture enough rainwater to meet demand. Storage capacity must be sufficient to store enough water to see the system and its users through the longest expected interval without rain. Hydrological data was analysed to obtain the potential rainwater harvested. Water demand and rainwater harvested were used to size the storage tank. Comparisons made between the storage tank below and above the ground.

\section{RESULTS AND DISCUSSION}

Water demand is the amount of water needed for nonpotable usage such as toilet flushing, watering plant and laundries. The amount of water demand, depends on the usage of the house and number of occupancy. The purpose of the harvested rainwater in this research is mainly for toilet flushing, watering plant and to fill washing machine for laundries purposes.
According to Federation of Malaysian Consumers Associations [5], each person only needed 80 litres of water a day which include the amount of water for drinking and household. However, the studied made by New Straits Time found that a Malaysian uses an average of 226 litres of water a day, compared with 155 litres in Singapore and 90 litres in Thailand. $26 \%$ of water usage is used for toilet flushing, $16 \%$ for car washing and gardening, $22 \%$ for washing machine and others for bath and house cleaning.

In this study, the data is obtained from an observation made based on the house that consists of 4 persons. The assumptions are; toilet is flushed five times per day, number of user is 4 persons and water usage of toilet flushing is 9 liters.

The consumption of water for watering plant covers $5 \%$ of the area of the house. Thus the amount of water needed for watering plant is assumed to be 25 litres per day. The consumption of water used for laundries covers $15 \%$ of the area of the house. It is assume that 75 litres of water is needed for this purposes per day. Total water demand of the selected house per month is $8.4 \mathrm{~m}^{3}$. Total water usage for daily, weekly, monthly and annually are shown in (Table 1).

Table -1: Total water demand (litre)for selected house

\begin{tabular}{|r|r|r|r|r|}
\hline Water use & Daily & Weekly & Monthly & Annually \\
\hline Toilet & 180 & 1260 & 5400 & 64800 \\
\hline $\begin{array}{r}\text { Watering } \\
\text { plant }\end{array}$ & 25 & 189 & 750 & 9125 \\
\hline Laundries & 75 & 525 & 2250 & 27000 \\
\hline Total & 280 & 1974 & 8400 & 100925 \\
\hline
\end{tabular}

Rainfall data from year 2002 to 2011 were collected from Drainage Irrigation Department (DID) Kota Samarahan District and plotted in (Figure 1). It is observed that the highest annual rainfall recorded is in 2003 and lowest in 2006 (Figure 1). The rainfall patterns are low on May until September from 2002 to 2011 consecutively.

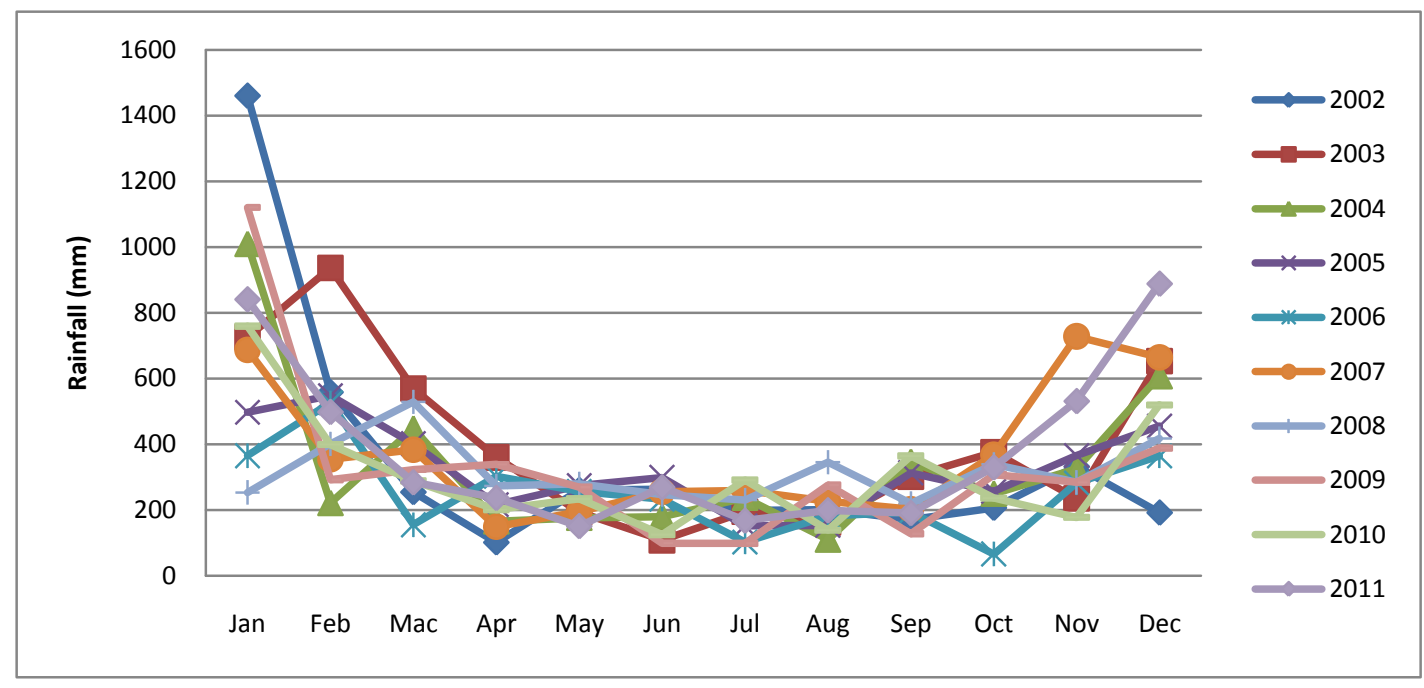

Fig -1: Rainfall variation from 2002 to 2011 
According to [6] there are two types to size the storage tank. Demand side approach is one of the methods used to design the rainwater storage tank. This method depends on the intensity of rainfall during the dry periods. This is because the tank is designed to store harvested water during the wet season for future use especially for dry seasons. For this studies, the monthly rainfall pattern for 2011 is used to design the storage tank. (Table -2) shows the monthly rainfall for Kota Samarahan in 2011.

Table -2: Monthly rainfall for Kota Samarahan in 2011

\begin{tabular}{|l|l|l|l|}
\hline Month & $\begin{array}{l}\text { Rainfall } \\
(\mathrm{mm})\end{array}$ & $\begin{array}{l}\text { Accumulated } \\
\text { rainfall } \\
(\mathrm{mm})\end{array}$ & $\begin{array}{l}\text { Percentage } \\
(\%)\end{array}$ \\
\hline Jan & 840.50 & 840.50 & 18.33 \\
\hline Feb & 498.00 & 1338.50 & 10.86 \\
\hline Mac & 284.00 & 1622.50 & 6.69 \\
\hline Apr & 236.50 & 1859.00 & 5.15 \\
\hline May & 151.00 & 2010.00 & 3.29 \\
\hline June & 269.00 & 2279.00 & 5.87 \\
\hline July & 167.50 & 2446.50 & 3.65 \\
\hline August & 199.00 & 2645.50 & 4.34 \\
\hline September & 190.50 & 2836.00 & 4.16 \\
\hline October & 329.50 & 3165.50 & 7.19 \\
\hline November & 531.00 & 3696.50 & 11.58 \\
\hline December & 888.00 & 4584.50 & 19.37 \\
\hline Total & 4584.50 & & 100.00 \\
\hline
\end{tabular}

The amount of water harvested affected by the catchment area. Basically, the larger the area the more water could be stored. The roof catchment area for selected house is $90 \mathrm{~m}^{2}$. Based on (Table -2), the lowest rainfall recorded is on May with a percentage of $3.29 \%$. Since May has lowest rainfall, the dry period is taken as 1 month. The required storage capacity is calculated by using (1).

$$
S=d * t
$$

Where,

$\mathrm{S}$ is the Required Storage Capacity,

$\mathrm{d}$ is the monthly demand and

$\mathrm{t}$ is the dry period

Supply side approach is another method used to design the proposed storage tank. Volume of harvested rainwater is calculated with (2). For this studies, the average annual rainfall of 2011 is used.

$$
V=a * r * c
$$

Where,

$\mathrm{V}$ is Water harvesting potential,

a is catchment area

$r$ is rainfall and

$\mathrm{c}$ is runoff coefficient

Run off coefficient for the catchment area assumed to be 0.9. Referring to (2), monthly harvested rainwater available equals to $31.01 \mathrm{~m}^{3}$. The basic rule for sizing storage tank is that the volume of water that can be captured and stored (inflow) must equal or exceed the volume of water demand (outflow). Therefore, The monthly water harvested (31.01 $\left.\mathrm{m}^{3}\right)$ can be replaced by the water demand $\left(8.4 \mathrm{~m}^{3}\right)$ since its volume is greater than monthly water demand. Figure 2, shows the comparison between the potential harvested rainwater and water demand. (Figure-2), illustrates that the water demand is less the potential harvested rainwater for every month in year 2011.

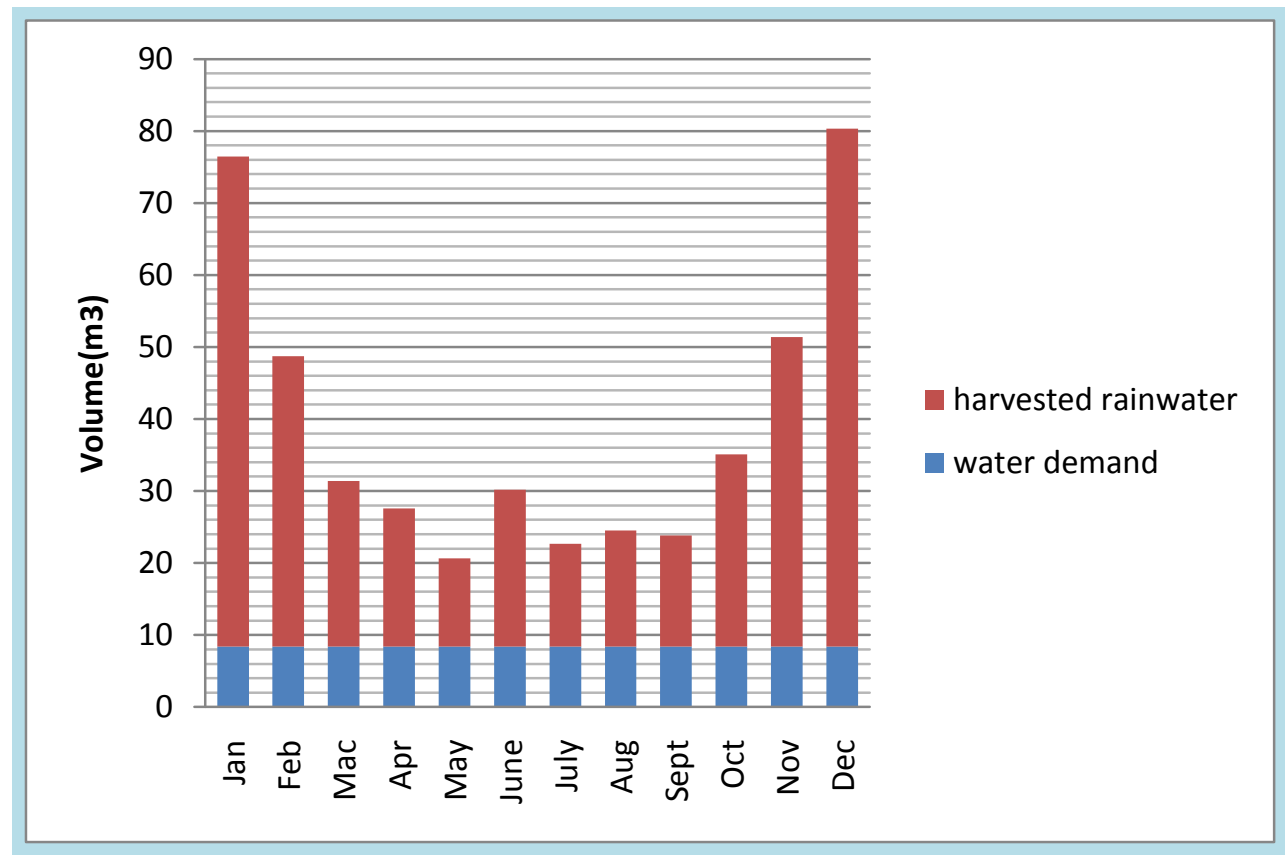

Fig -2: Comparison between monthly harvested rainwater and water demand for 2011 
(Table-3), shows cumulated rainfall harvested (inflow) and demand (outflow) from the storage tank which is used for sizing the tank. The storage requirement in the end of the year is $271.27 \mathrm{~m}^{3}$. This volume of water have to be stored to cover the shortfall during the dry period. For this study, the suitable model of storage tank is R18CCfrom WEIDA Resources Sdn.

Table -3: Accumulated rainfall harvested (inflow), demand (outflow)

\begin{tabular}{|l|l|l|l|l|}
\hline Month & $\begin{array}{l}\text { Inflow } \\
\left(\mathrm{m}^{3}\right)\end{array}$ & $\begin{array}{l}\text { Demand } \\
\left(\mathrm{m}^{3}\right)\end{array}$ & $\begin{array}{l}\text { Outflow } \\
\left(\mathrm{m}^{3}\right)\end{array}$ & $\begin{array}{l}\text { Inflow - } \\
\text { Outflow } \\
\left(\mathrm{m}^{3}\right)\end{array}$ \\
\hline January & 68.08 & 8.40 & 8.40 & 59.68 \\
\hline February & 108.41 & 8.40 & 16.80 & 91.61 \\
\hline March & 131.42 & 8.40 & 25.20 & 106.22 \\
\hline April & 150.57 & 8.40 & 33.60 & 116.97 \\
\hline May & 162.81 & 8.40 & 42.00 & 120.81 \\
\hline June & 184.59 & 8.40 & 50.40 & 134.19 \\
\hline July & 198.89 & 8.40 & 58.80 & 140.09 \\
\hline August & 215.01 & 8.40 & 67.20 & 147.81 \\
\hline September & 230.44 & 8.40 & 75.60 & 154.84 \\
\hline October & 257.13 & 8.40 & 84.00 & 173.13 \\
\hline November & 300.14 & 8.40 & 92.40 & 207.74 \\
\hline December & 372.07 & 8.40 & 100.80 & 271.27 \\
\hline Total & & 100.80 & & \\
\hline
\end{tabular}

If storage tank is designed below or on the ground, gravity flow is not possible, hence a small pump may be required to move the water. According to [7], the electricity price for domestic customer is RM 21.80 sen per month for the first $200 \mathrm{kwh}$. The minimum monthly charge is RM3.00 Electricity consumption can be calculated by (3).

$$
P=\left(\frac{w}{1000}\right) * t_{0} * t_{a}
$$

Where,

$P$ is Electricity consumption,

$w$ is power (watts), hours of operation,

$t_{0}$ is hours of operation and

$t_{\alpha}$ is tariff

(Table -4), shows the electricity consumption needed to operate a pump for 24 hours per day.

Table -4: Electricity consumption needed to operate a pump

\begin{tabular}{|l|l|l|}
\hline Time & $\begin{array}{l}\text { Electricity consumption } \\
(\mathrm{kwh})\end{array}$ & $\begin{array}{l}\text { Electricity price } \\
(\mathrm{RM})\end{array}$ \\
\hline Daily & 6.00 & 3.00 \\
\hline Weekly & 42.00 & 9.15 \\
\hline Monthly & 168.00 & 36.64 \\
\hline Yearly & 2016.00 & 439.48 \\
\hline
\end{tabular}

Material cost for the rainwater harvesting system below or on the ground is shown in (Table -5). Hence total cost of the system with $5 \%$ yearly cost for maintenance and electricity consumption equals to RM 1807.63.

Table -5: Total installation cost

\begin{tabular}{|l|l|l|l|}
\hline Material & $\begin{array}{l}\text { Rate } \\
(\mathrm{RM})\end{array}$ & $\begin{array}{l}\text { No of } \\
\text { unit }\end{array}$ & $\begin{array}{l}\text { Amount } \\
(\mathrm{RM})\end{array}$ \\
\hline Storage Tank $\left(1.800 \mathrm{~m}^{\mathrm{a}}\right)$ & 480 & 1 & 480 \\
\hline Gutter (uPVC) & 49 & 1 & 49 \\
\hline Clip (for gutter) pipe \& & 4 & 1 & 4 \\
\hline $\begin{array}{l}\text { uPVC Down } \\
\text { Conveyance Pipe (75 mm } \\
\text { diameter) }\end{array}$ & 2 & 70 \\
\hline Pump (14.61 $\left.\mathrm{kg} / \mathrm{cm}^{2}\right)$ & 600 & 1 & 600 \\
\hline Installation & & & 100 \\
\hline & & Total & 1303 \\
\hline
\end{tabular}

The proposed rainwater harvesting is a simple system which consists of a catchment area, gutters and downspouts and a means of distribution which operates by gravity. The storage tank is placed above the ground and is support by the tank holder. Gravity method can reduce the electric consumption to operate the pump. Similarly, total cost of installation and yearly maintenance is RM 738.15. Cost comparison of Rainwater harvesting system with and without pump is shown in (Table -6).

Table -6: Cost comparison of Rainwater harvesting system with and without pump

\begin{tabular}{|l|l|l|l|l|}
\hline $\begin{array}{l}\text { Compone } \\
\text { nt }\end{array}$ & $\begin{array}{l}\text { Installati } \\
\text { on cost } \\
(\mathrm{RM})\end{array}$ & $\begin{array}{l}\text { Electricity } \\
\text { cost/year } \\
(\mathrm{RM}\end{array}$ & $\begin{array}{l}\text { Maintenance } \\
\text { /year } \\
(\mathrm{RM})\end{array}$ & $\begin{array}{l}\text { Total } \\
\text { cost } \\
(\mathrm{RM})\end{array}$ \\
\hline $\begin{array}{l}\text { With } \\
\text { pump }\end{array}$ & 1303.00 & 439.48 & 65.15 & $\begin{array}{l}1807.6 \\
3\end{array}$ \\
\hline $\begin{array}{l}\text { Without } \\
\text { pump }\end{array}$ & 703.00 & - & 35.15 & 738.15 \\
\hline
\end{tabular}

(Table -6), indicates that there are often additional costs associated with an underground system which are not necessarily present with a system installed above the ground. Some of these costs may include; excavation, backfill, drainage pipe trenches, and depending on the tank and delivery costs.

\section{CONCLUSION}

Malaysia has a high potential to implement rainwater harvesting system since it is one of the country that having a high intensity of rainfall every year. The implementation of rainwater harvesting can help to reduce the use of treated water from being use as non-portable purposes. With this system, the demand for treated water can be replaced with harvested rainwater as non-portable purposes such as toilet flushing, watering plant and other cleaning purposes. 
Water demand for the selected house is $8.4 \mathrm{~m}^{3}$ per month where the system can provide $31.01 \mathrm{~m}^{3}$ per month. This means that the rainwater harvesting system can support the water demand of the selected house throughout a year even during the dry season which is in May.

The analysis shows that the concept of rainwater harvesting technique above the ground is more beneficial as compared to the storage tank below or on the ground. Installation cost for RWH above the ground is RM703 (system does not required to pump water) where, cost for installation RWH below the ground is RM 1303.

Although rainwater harvesting system can ease the user in term of reducing the demand on treated water, but this harvested rainwater can be limited if it is not well-managed. The precautions need to be taken especially during the dry seasons. The owner needs to save the water by limiting the usage of harvested rainwater on non-portable use. Since the amount of water that use to fills the flushing toilet is not adjustable, the owner can only control the use of water for watering plant and other cleaning purposes.

\section{ACKNOWLEDGEMENTS}

The authors would like to thank the Department of Civil Engineering, Faculty of Engineering UNIMAS, Sarawak for their continuous support and kindness; as well as the Department of Irrigation and Drainage Sarawak for providing the required hydrology data as well as technical knowledge.

\section{REFERENCES}

[1]. International Commission On Large Dams, ICOLD. (2013). Retrieved 2010-04-21 [Online]: http://www.icoldcigb.org.

[2]. Che-Ani A.I, Shaari N, A.Sairi, M.F.M.Zain, MM.Tahir. (2009). Rainwater Harvesting as an alternative water supply in the future, European Journal of Scientific Research vol.34 No.1, pp.132-140.

[3]. Christoper kloss. (2008). Rainwater Harvesting Policies, Municipal Handbook, Retrieved on October 4, 2014 from http://water.epa.gov/infrastructure/greeninfrstructure/upload /gimunic handbook_harvesting.pdf.

[4]. Thomas, T.H.; Martinson, D.B. (2007). Roofwater Harvesting, A Handbook for Practitioners. Delft:IRC

International Water and Sanitation Centre, URL [Accessed: 11.03.2011]. pdf.

[5]. Federation of Malaysian Consumers Associations (FOMCA). (2010). Retrieved on October 6, 2014 from Online:http://www.researchsea.com/html/institutions.php/iid /127/research/federation of malaysian consumers associations.

[6]. Janette, W. Hattum, T. V. (2010). Rainwater harvesting for domestic use, ISBN Agromisa: 90-8573-053-8, Agromisa, Foundation and CTA, Wageningen, , pp.35-40.

[7]. Tenga Nasional Berhad. (2014). Tariff and pricing, 2014, Retrieved on October 4, 2014 from [Online]: http://www.alacrastore.com/company-snapshot/Tenaga-

Nasional-Bhd-1052748.

\section{BIOGRAPHY}

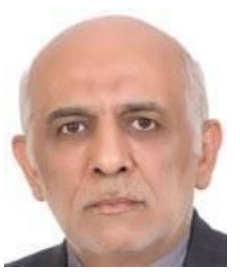

Associate Professor Dr. Nasser is specialized in Hydraulic Structures. He has in his credit teaching, research, industrial, and managerial within the government experiences of more than thirty years in the field of Hydraulic structures, Hydropower, sedimentation, Hydrology, flood control, Water Resources Planning and Value Engineering. 